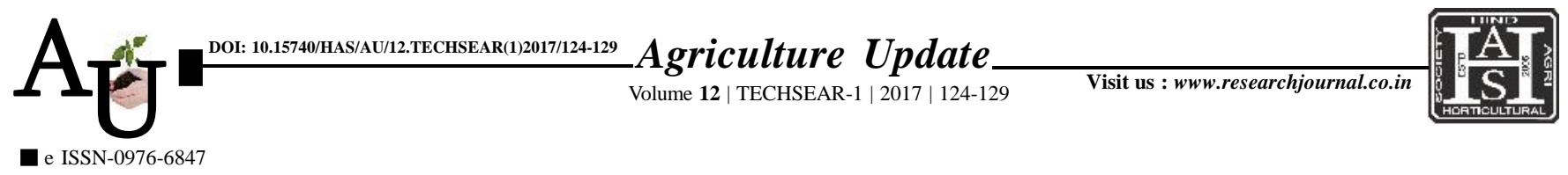

\title{
Research Article: Effect of chemical weed management on quality parameters, yield parameters and yield in sugarcane in western zones of Tamil Nadu
}

\section{SUGANTHI AND P. MUTHUKRISHNAN}

Article Chronicle : Received : 05.07.2017;

Accepted : 22.07.2017

KEY WoRDS:

Halosulfuron methyl, Chlorimuron ethyl, Chemical weed management, Sugarcane

Author for correspondence :

\section{SUGANTHI}

Department of

Agronomy, Tamil Nadu Agricultural University, COIMBATORE (T.N.) INDIA Email:vet12sugan@gamil. com

See end of the article for authors' affiliations
SUMMARY : Field experiment was conducted from October 2011 to Feb. 2013 in sugarcane at Tamil Nadu Agricultural University, Coimbatore to find out the influence of chemical weed management on total weed density, weed control efficiency on yield attributes, yield and quality parameters in sugarcane. The experiments were laid out in a Randomized Block Design with three replications. The treatments included four doses of halosulfuron methyl $\left(60,90,120,180 \mathrm{~g} \mathrm{ha}^{-1}\right)$ chlorimuron ethyl $(24,36,48$ and 72 $\left.\mathrm{g} \mathrm{ha}^{-1}\right)$ and halosulfuron methyl + chlorimuron ethyl (combi) $\left(60,90.120\right.$ and $\left.180 \mathrm{~g} \mathrm{ha}^{-1}\right)$ compared with atrazine $\left(2.0{\left.\mathrm{k} . \mathrm{g} \mathrm{ha}^{-1}\right)}\right)$ hand weeding and unweeded control. The results of the experiments showed that, post emergence application of combi at 120 and $180 \mathrm{~g} \mathrm{ha}^{-1}$ and chlorimuron ethyl at 48 and $72 \mathrm{~g} \mathrm{ha}^{-1}$ offered better weed control and resulted in increased plant growth and yield attributes which resulted in increased cane yield and didn't show any significant variation in quality parameters. This was comparable with recommended weed control methods of pre emergence application of atrazine at $2.0 \mathrm{~kg}$ $\mathrm{ha}^{-1}$ and hand weeding on 30 DAP.

How to cite this article : Suganthi, M. and Muthukrishnan, P. (2017). Effect of chemical weed management on quality parameters, yield parameters and yield in sugarcane in western zones of Tamil Nadu. Agric. Update, 12(TECHSEAR-1) : 124-129; DOI: 10.15740/HAS/AU/12.TECHSEAR(1)2017/124-129. 